\title{
The Relation between Neutrophil Lymphocyte Count Ratio (NLCR) and Dengue Infection Grade of Severity in Adult Patients in RS Muhammadiyah Ahmad Dahlan Kediri in January 2019
}

\author{
Dylan Candra Yuditya ${ }^{*}$, Imam Sudirgo ${ }^{2}$ \\ ${ }^{1}$ General Practitioner of Muhammadiyah Ahmad Dahlan Hospital Kediri, Indonesia \\ ${ }^{2}$ Internist of Muhammadiyah Ahmad Dahlan Hospital Kediri, Indonesia \\ candra.dylan@gmail.com
}

\begin{abstract}
In Indonesia, dengue viral infection is one of the problems of public health that is increasing in the amount of people infected and the spread of the disease. Platelet and hematocrit are used to be the indicators to determine the progress of the disease, but the count of leucocyte is sometimes less concerned. It is known that approximately $80 \%$ of the leucocytes are neutrophils and lymphocytes. Therefore, the purpose of this study was to determine the relation between neutrophil lymphocyte count ratio (NLCR) and dengue infection grade of severity in adult patients in RS Muhammadiyah Ahmad Dahlan Kediri in January 2019. This study is an analytical observational research with cross-sectional design. The subjects of this study were adult patients (14 years old and above) infected by dengue virus, that had fulfilled the inclusive criteria and the exclusive criteria. The data used in this study was secondary data from the medical record of the patients who suffered from dengue infection in RS Muhammadiyah Ahmad Dahlan Kediri in January 2019. Then the data was analyzed by Spearman's test to know the relation between neutrophil lymphocyte count ratio (NLCR) and dengue infection grade severity in adult patients. The result of Spearman's test showed that $\mathrm{p}$ value $=0.000(\mathrm{p}<0.05)$ and the result of contingency coefficient test was -0.733 . There is a significant relation between NLCR and dengue infection severity index in adult patients. The lower the NLCR, the dengue infection grade will be more severe.
\end{abstract}

Keywords: NLCR, Dengue Viral Infection, Dengue Hemorrhagic Fever, Severity

Received December, 25, 2019; Revised January 24, 2020; Accepted February 15, 2020 


\section{STRADA Jurnal Ilmiah Kesehatan}

DOI: $10.30994 /$ sjik.v9i1.265

ISSN: 2252-3847 (print); 2614-350X (online)

Vol.9 No.1. May 2020. Page.20-25

\section{INTRODUCTION}

In Indonesia, Dengue Hemorrhagic Fever (DHF) is one of the diseases that continue to raise the number of incidents and widen the spread over the country. DHF is a mosquito-borne viral disease that usually infects children and teenagers under 15 years old, but it also infects adults in general (Kementrian Kesehatan Republik Indonesia, 2018).

Total incidents of DHF in Indonesia happened on 2017 was 68,407 cases. The province with the highest incidents happened in Java Island was in West Java with 10,016 cases. The second position was East Java with 7,838 cases (Kementrian Kesehatan Republik Indonesia, 2018).

Kediri District Health Office reported that in 2018, there was a total of 215 DHF cases, and among those, there was 1 death case (Dinas Kesehatan Kota Kediri, 2019). The latest report in 2019 in Kediri, there were 185 cases from January through May 2019, 2 deaths were reported (Dinas Kesehatan Kota Kediri, 2019).

Dengue is a mosquito-borne viral infection transmitted by Aedes spp. mosquitoes. Dengue virus is from Flaviviridae family, it has 4 serotypes: DEN-1, DEN-2, DEN-3, and DEN-4. Clinically, patients infected by dengue virus disease development are differentiated by 3 phases, which are febrile phase, critical phase, and recovery phase. According to the severity of the infection, WHO (1997) defined the severity grade into Dengue Fever (DF), Dengue Hemorrhagic Fever (DHF) with grade I, II, III, and IV.

The indicator that shows the development of the disease besides the clinical findings is complete blood count (CBC). WHO criteria (2011) defined that some components of CBC like leucocytes, platelets, and hematocrits are important for figuring out the clinical development of dengue. Commonly, platelet count and hematocrit are used as the indicator of the development of dengue infection, while in the other hand leucocyte count is less concerned (Risniati et al, 2011). Neutrophils and lymphocytes are $80 \%$ of the leucocytes and have the active role as body response to inflammation and infection so that immune response can be drawn from the proportion of those 2 cell types (Gurol et al, 2015).

The latest researches have used the neutrophil and lymphocyte count ratio (NLCR) as a marker to differentiate between bacterial infections and viral infections which the cut off is 6.2 (Holub et al, 2011). Dengue severity grade is also known that it is related to the inflammation occurred on dengue infection because of the exaggerating response of the immune system (Irmayanti et al, 2017).

From the problems mentioned above, researcher wants to know the relation between NLCR and dengue infection grade of severity in RS Muhammadiyah Ahmad Dahlan Kota Kediri in period January 2019.

\section{METHODS}

This study is an analytical observational research with cross-sectional design. The population of this study were adult patients (14 years old and above) infected by dengue virus in RS Muhammadiyah Ahmad Dahlan Kediri in January 2019 and total sampling technique was used to select the subjects. The study contains of 2 variables, NLCR as the dependent variable and dengue grade of severity as the independent variable. The data used in this study was secondary data from the medical record of the patients who suffered from dengue infection in RS Muhammadiyah Ahmad Dahlan Kediri in January 2019.

There were inclusive criteria and exclusive criteria made for the subjects. The inclusive criteria are patients who hospitalized because of dengue viral infection, $\geq 14$ years old, the result of the blood test used was the examination in $3^{\text {rd }}$ or $4^{\text {th }}$ day of fever, the patient has complete medical record status. Meanwhile, the exclusive criteria are patient who has dual 


\section{STRADA Jurnal Ilmiah Kesehatan}

DOI: $10.30994 /$ sjik.v9i1.265

ISSN: 2252-3847 (print); 2614-350X (online)

Vol.9 No.1. May 2020. Page.20-25

infection beside the dengue viral infection, < 14 years old, incomplete medical record status. All subjects must fulfill the inclusive and exclusive criteria.

Then, the data was analyzed by Kolmogorov smirnov to determine the data distribution. Because the distribution of the data was abnormal, the Spearman's test was used to know the relation between neutrophil lymphocyte count ratio (NLCR) and dengue infection severity grade in adult patients with SPSS Program.

\section{RESULTS}

Total subjects in this study were 76 patients, consist of 43 men (56.6\%) and 33 women (43.4\%). Patients infected by dengue virus mostly in the age of 17 to 25 years old. Based on patient's length of stay in the hospital, 47 patients $(61.9 \%)$ hospitalized for $\leq 4$ days while 29 patients $(39.1 \%)$ hospitalized for $>4$ days. According to the dengue severity grade, 54 patients $(71.1 \%$ ) suffered from Dengue Hemorrhagic Fever (DHF) grade I, 14 patients (18.4\%) suffered from DHF grade II, and 8 patients $(10.5 \%)$ suffered from DHF grade III.

Table 1. Subject characteristic based on gender

\begin{tabular}{lll}
\hline Gender & Frequency $(\mathbf{n})$ & Percentage $(\boldsymbol{\%})$ \\
\hline Male & 43 & 56.6 \\
\hline Female & 33 & 43.4 \\
\hline Total & 76 & 100 \\
\hline
\end{tabular}

Table 2. Subject characteristic based on age group

\begin{tabular}{lll}
\hline Age Group & Frequency $(\mathbf{n})$ & Percentage $(\boldsymbol{\%})$ \\
\hline$<\mathbf{1 7}$ years old & 19 & 25 \\
\hline $\mathbf{1 7}-\mathbf{2 5}$ years old & 36 & 47.4 \\
\hline $\mathbf{2 6}-\mathbf{3 5}$ years old & 14 & 18.4 \\
\hline $\mathbf{3 6}-\mathbf{4 5}$ years old & 5 & 6.6 \\
\hline $\boldsymbol{>} \mathbf{4 5}$ years old & 2 & 2.6 \\
\hline Total & 76 & 100 \\
\hline
\end{tabular}

Table 3. Subject characteristic based on length of stay in hospital

\begin{tabular}{lll}
\hline Length of stay & Frequency $(\mathbf{n})$ & Percentage $(\boldsymbol{\%})$ \\
\hline $\mathbf{4}$ days & 47 & 61.9 \\
\hline > 4 days & 29 & 39.1 \\
\hline Total & 76 & 100
\end{tabular}

Table 4. Subject characteristic based on DHF severity grade

\begin{tabular}{lll}
\hline DHF Severity Grade & Frequency $(\mathbf{n})$ & Percentage $\mathbf{( \% )}$ \\
\hline Grade I & 54 & 71.1 \\
\hline Grade II & 14 & 18.4 \\
\hline Grade III & 8 & 10.5 \\
\hline Grade IV & 0 & 0 \\
\hline Total & 76 & 100
\end{tabular}

The result of Spearman's test showed that $p$ value $=0.000$ and the result of contingency coefficient test was -0.733 . Because $p<0.05$ means there is significant relation between NLCR and dengue severity grade. $C>0.5$ shows that there is a strong relation between 2 


\section{STRADA Jurnal Ilmiah Kesehatan}

DOI: $10.30994 /$ sjik.v9i1.265

ISSN: 2252-3847 (print); 2614-350X (online)

Vol.9 No.1. May 2020. Page.20-25

variables of the research. The negative value means there is opposite direction between 2 variables, the lower the NLCR, the higher severity grade of dengue viral infection.

\section{DISCUSSION}

Dengue infection commonly causes leucopenia. Leucopenia is a marker which indicates that the febris will go down and the patient will enter the critical phase. In critical phase, the leucocyte count will decline $\left(<5000 \mathrm{cells} / \mathrm{mm}^{3}\right)$ and neutrophil and lymphocyte count ratio will change where neutrophil will decrease so that neutrophil count is less than lymphocytes. That conditions will be the predictor of critical phase in which plasma leakage occurs. The change happens before thrombocytopenia or raising hematocrit occurs. Relative lymphocytosis with increasing atypical lymphocytosis is usually found later in the febrile phase or in the recovery phase (WHO, 2011).

The neutropenia condition is caused by the virus infection which causes the neutrophil to apoptosis because the apoptosis rate of neutrophils has a positive correlation with disease severity grade thus it supports protective role of neutrophil in antiviral response (Galani, 2015). That statement is also supported by Candra (2010) who stated that dengue severity grade has a close relation with the exaggerating inflammation occurred because of excessive immune response.

Based on this research, there is a significant relation between NLCR and dengue severity grade in adults in RS Muhammadiyah Ahmad Dahlan Kota Kediri in January 2019. This result corresponds with Irmayanti et al's statement (2017) that showed there was a relation between NLCR and dengue infection ( $p<0.05)$. The mean NLCR on DHF grade I is 2.19 and DHF grade II is 0.80 so that the lower the NLCR, the dengue infection will be more severe.

Another cross sectional research done in RSUP Dr. Kariadi and RSND Semarang showed that there was a statistically significant difference between NLCR and DF and DHF. This research showed that NLCR in DHF group is lower (mean NLCR $=0.55$ ) than DF group (mena NLCR = 1.23) (Yuntoharjo et al, 2018).

Karla et al's research (2015) showed a contrast result from this research that concluded there was no significant relation between NLCR and dengue severity grade $(p=0.63)$. From her explanation, things that could affect the result were quality and type of the tools used, laboratory staff's examination skill and taking blood samples on different days of fever $\left(2^{\text {nd }}-7^{\text {th }}\right.$ day of fever $)$. In the other hand though, this research used samples from $3^{\text {rd }}$ and $4^{\text {th }}$ day of fever.

\section{CONCLUSION}

There is a significant relation between NLCR and dengue infection severity grade in adult patients in RS Muhammadiyah Ahmad Dahlan Kediri in January 2019. The lower the NLCR, the dengue infection grade will be more severe.

\section{REFERENCES}

Candra, \& Aryu. (2010). Demam Berdarah Dengue: Epidemiologi, Patogenesis, dan Faktor Risiko Penularan. [Accessed fromhttp://ejournal.litbang.depkes.go.id/index.php/aspirator/article/view/2951/2136 on 11 June 2019 at 20.00].

Dinas Kesehatan Kota Kediri. (2019). Data Infeksi Virus Dengue Kota Kediri Penyakit Demam Berdarah Tahun 2018. Kediri. 
Galani, I., E., \& Andreakos, E. (2015). Neutrophils in viral infection: Current concepts and caveats. [Accessed from: https://jlb.onlinelibrary.wiley.com/doi/full/10.1189/jlb.4VMR1114-555R on 10 June 2019 at 17.00].

Ginting, F. et al. (2017). Pedoman Diagnostik dan Tata Lakasana Infeksi Dengue dan Demam Berdarah Dengue Menurut Pedoman WHO 2011. [Accessed from http://repository.usu.ac.id/bitstream/handle/123456789/63599/096\%20.pdf?sequen ce $=1$ on 10 June 2019 at 19.00].

Gurol, G., Ciftci, I., H., Terzi, H., A., Atasoy, A., R., Ozbek, A., Koroglu, M. (2015). Are there standardized cutoff values for neutrophil-lymphocyte ratios in bacteremia or sepsis? J Microbiol Biotechnol. 25(4):521-5.

Hadinegoro, S., R., H., Ismoedijanto, M., \& Chairulfatah, A. (2014). Pedoman diagnosis dan tatalaksana infeksi virus dengue pada anak. Jakarta: Ikatan Dokter Anak Indonesia.

Holub, M., Beran, O., Kasprikova, N., Chalupa, P. (2011). Neutrophil to lymphocyte count ratio as a biomarker of bacterial infection. [Accessed from https://link.springer.com/article/10.2478/s11536-012-0002-3 on 11 June 2019 at 20.00].

Irmayanti,, I., Nurulita, A., \& Sennang, N. (2017). Rasio neutrophil/limfosit pada demam berdarah dengue. [Accessed from https://www.researchgate.net/publication/328279940_NEUTROPHILLYMPHOC YTE_COUNT_RATIO_ON_DENGUE_HEMORRHAGIC_FEVER_Rasio_Netrof ilLimfosit_pada_Demam_Berdarah_Dengue on 9 June 2019 at 20.05].

Kementrian Kesehatan Republik Indonesia, 2018. Info DATIN Kemenkes RI: Situasi Penyakit Demam Berdarah di Indonesia Tahun 2017. [Accessed from http://www.depkes.go.id/download.php?file=download/pusdatin/infodatin/InfoDati n-Situasi-Demam-Berdarah-Dengue.pdf on 10 June 2019 at 17.09]

Nusa, K., C., Mantik, M., F., J., Rampengan, N. (2015). Hubungan Ratio neutrophil dan Limfosit pada penderita infeksi virus dengue. [Accessed from http://download.garuda.ristekdikti.go.id/article.php?article=291809\&val=1001\&titl $\mathrm{e}=$ HUBUNGAN\%20RATIO\%20NEURTOFIL\%20DAN\%20LIMFOSIT\%20PAD A\%20PENDERITA\%20PENYAKIT\%20INFEKSI\%20VIRUS\%20DENGUE on 10 June 2019 at 18.00$]$.

Risniati, Y., Tarigan, L., H., Tjitra, E. (2011). Leukopenia sebagai predictor terjadinya sindrom syok dengue pada anak dengan demam berdarah dengue di RSPI Prof. dr. Sulianti Saroso. Media Litbang kesehatan, 21(3) pp.96-100.

Septiani, G., \& IDAI. (2009). Demam Berdarah dengue, masalah dan cara penanggulangannya. 


\section{STRADA Jurnal Ilmiah Kesehatan}

DOI: $10.30994 /$ sjik.v9i1.265

ISSN: 2252-3847 (print); 2614-350X (online)

Vol.9 No.1. May 2020. Page.20-25

[Accessed from https://ginaseptiani.wordpress.com/2009/04/25/demam-berdarah-denguemasalah-dan-cara-penanggulangannya/ on 1 July 2019 at 10.00].

Sridianti. (2014). Pengertian Leukosit. [Accessed from http://www.sridianti.com/pengertian-leukosit.html on 9 June 2019 at 19.00].

Sutaryo, S. (2014). Dengue. Yogyakarta: Medika Fakultas Kedokteran Universitas Gajah Mada.

Newman, W., A., D. (2015). Kamus Saku Kedokteran Dorland, EGC Medical Publisher. doi: 10.1097/00000441-196003000-00040.

World Health Organization. (2009). Dengue Hemorrhagic fever, Diagnosis: treatment, prevention and control. $2^{\text {nd }}$ ed. Geneva: WHO.

World Health Organization. (2011). "Comprehensive guideline for prevention and control of dengue and dengue haemorrhagic fever". [Accessed from http://apps.searo.who.int/pds_docs/B4751.pdf on 13 Juni 2019 at 09.46].

World Health Organization. (2019). Dengue and Severe Dengue. [Accessed from

https://www.who.int/news-room/fact-sheets/detail/dengue-and-severe-dengue on 20 June 2019 at 20.05].

Yuntoharjo, P., J., I., Arkhaesi, N., \& Hardian. (2018). Perbandingan antara Nilai Rasio Neutrofil Limfosit (NLCR) pada Anak dengan Demam Dengue dan Demam Berdarah Dengue. [Accessed from https://ejournal3.undip.ac.id/index.php/medico/article/view/20741/19456 on 13 Juni 2019 at 10.00]. 